\title{
FIKIH TOLERANSI DI PESANTREN DALAM PERSPEKTIF SOSIOLOGI HUKUM ISLAM
}

\author{
Abdul Ghoni \\ Alumni Program S3 SPS UIN Syarif Hidatullah Jakarta \\ Dosen STIU Al-Hikmah Jakarta \\ Email: ghoni75@yahoo.co.id
}

\begin{abstract}
:
This study is conducted in order to analyze the fiqh of tolerance in traditional and modern pesantren. This study is a kind of Islamic sociology of law which analyzes empirically how the response of community toward the value of tolerance. This study uses quantitative method in order to know the level of tolerance of five pesantren in Java. Those pesantren are Darunnajah Pesantren in Jakarta (1961), Rafah Pesantren in Bogor (1997), Ibnu Abbas Pesantren in Klaten (2007) which represent modern pesantren and Babussalam Pesantren in Bandung (1981), Al-Ishlah Pesantren in Kediri (1954) which represent traditional pesantren. The result of this study indicates that the traditional pesantren is better than the modern pesantren on the level of external tolerance, while the modern pesantren is better than the traditional pesantren on the level of internal tolerance.
\end{abstract}

\begin{abstract}
Abstrak:
Penelitian ini dilakukan untuk mendeskripsikan fikih toleransi yang ada di pesantren baik pesantren tradisional dan pesantren modern. Penelitian ini termasuk kajian sosiologi hukum Islam, yang mengkaji secara empiris nilai toleransi sebagai salah satu produk hukum Islam terkait dengan bagaimana interaksi dan perilaku masyarakat terhadap nilai toleransi tersebut. Penelitian dilakukan secara kuantitatif terhadap 5 Pesantren di Pulau Jawa, yaitu; Pesantren Darunnajah Jakarta (1961), Pesantren Rafah Bogor (1997), Pesantren Ibnu Abbas Klaten (2007) yang merepresentasikan pesantren modern, dan Pesantren Babussalam Bandung (1981), Pesantren Al-Ishlah Kediri (1954) yang merepresentasikan pesantren tradisional. Kesimpulan dari penelitan ini adalah bahwa pesantren tradisional memiliki tingkat toleransi eksternal yang lebih tinggi dari pesantren modern, sementara pesantren modern memiliki tingkat toleransi internal yang lebih tinggi daripada pesantren tradisional.
\end{abstract}

Kata Kunci: fikih toleransi, pesantren modern, pesantren tradisional, toleransi internal, toleransi eksternal. 


\section{PENDAHULUAN}

Keragaman adalah bagian dari realitas di Indonesia. Indonesia adalah negara yang paling banyak keragamannya. Indonesia terdiri dari 17.000 pulaudengan keragaman bahasa, adat, dan tradisi. ${ }^{1}$ Di samping itu Indonesia merupakan negara yang mengharuskan setiap warganya untuk memeluk agama tertentu. Lyn Parkermenyebut Indonesia sebagaireligious state, bukan secular state maupun Islamic state. Maksud dari sebutan religious state adalah setiap warga negara diharuskan memilih salah satu dari 6 agama resmi yang diakui pemerintah. ${ }^{2}$ Secara normatif, tidak ada agama yang melegalkan sikap intoleransi terhadap sesama pemeluk suatu agama atau pemeluk agama lain. $^{3}$

Namun demikian beberapa konflik sosial terjadi karena keragaman agama. Di antaranya adalah fenomena penghancuranterhadap tempat ibadah agama tertentu. Laporan CRCS tahun 2012 menyebutkan bahwa setidaknya ada tiga peristiwa besar terkait dengan konflik sosial yang disebabkan oleh perbedaan agama, seperti; penghancuran GKI Taman Yasmin Bogor, HKBP Filadelfi di Bekasi, dan GKPPD di Aceh Singkil. ${ }^{4}$ Konflik sosial di Indonesia juga dapat terjadi dalam satu agama seperti sesama Muslim. Fenomena keragaman mazhab kadangkala dipersepsikan seperti perbedaan agama.Di antara Fenomena keseharian yang masih berpotensi menimbulkan konflik terkait hukum bacaan doa Qunu>t. Sebagian berpendapat bahwa doa Qunut adalah bagian dari $a b^{\prime}$ 'ad al-salahyang jika ditinggalkan maka dianjurkan untuk sujud sahwi, sementara pendapat lain tidak menjadikannya sebagai bagian dari shalat Subuh. Konflik karena perbedaan mazhab kadang kala masih terjadi di ingkungan pesantren. ${ }^{5}$ Realitas tersebut menunjukkan bahwa

${ }^{1}$ Bernard Adeney-Risakotta, ed. Dealing with Diversity; Religion, Globalization, Violence, Gender, and Disaster in Indonesia, (Geneva: Globethics.net International Secretariat, 2014), 21.

${ }^{2}$ Lyn Parker, "Religious Tolerance and Inter-Faith Education in Indonesia", Biennial Conference of the Asian Studies Association, (2010): 3.

${ }^{3}$ Q.S. Al-Mumtahanah: 8.

${ }^{4}$ Zainal Abidin Bagir, dkk.,Laporan Tahunan Kehidupan Beragama di Indonesia 2012, (Yogyakarta: CRCS-UGM, 2012), 30.

${ }^{5}$ Ada sebuah pesantren di wilayah Bogor yang mengajarkan fikih dengan pendekatan keragaman mazhab kepada santrinya. Pesantren tersebut memiliki agenda tahunan berupa program PKL (Praktek Kerja Lapangan), di mana para santri tingkat akhir diperbantukan selama sebulan di beberapa pesantren yang ada di sekitar pesantren tersebut. Salah seorang santri mendapat tugas PKL di pesantren dengan kebiasaan bahwa imam membaca basmalah dengan jelas saat membaca suratal-Fatihah pada shalat jahr (Maghrib, Isya, dan Subuh). Pada hari pertama PKL, santri tersebut dipersilahkan untuk menjadi imam shalat Maghrib. Kemudian tanpa disadari, ia membaca surat Al-Fatihahtanpa bacaan "basmalah". Selesai shalat berjamaah, pimpinan pesantren langsung berdiri dan mengkritik sang imam di hadapan seluruh santri. Sebelumnya, santri yang mengikuti program PKL diajarkan fikih dengan buku pegangan Bidayat al-Mujtahid karangan Ibnu Rushd. Salah salah satu pembahasan dalam buku tersebut adalah mengenai hukum membaca "basmalah" ketika membaca surat $A l$ Fatihah. Ada beberapa pendapat terkait permasalahanl ini. Malik melarang bacaan basmalah

INDO-ISLAMIKA, Volume 5 No. 2 Juli - Desember 2015/1438 | 213 


\section{Abdul Ghoni}

penanaman nilai toleransi adalah hal yang sangat penting untuk meredam konflik social tersebut.

Di antara komunitas yang perlu mendapat perhatian terkait dengan penanaman nilai toleransi adalah komunitas yang tinggal di lingkungan pesantren, Menurut Azyumardi Azra, pesantren adalah lembaga pendidikan yang telah mampu terus bertahan dalam berbagai keadaan. Pesantren telah berperan signifikan dalam dunia pendidikan Indonesia lebih dari satu abad lamanya. Pesantren pun telah melakukan berbagai perubahan internal sehingga dapat terus maju dan berkembang, baik dari sisi kelembagaan, kurikulum, maupun dari ideologi ataupun prinsipnya. ${ }^{6}$

Namun di sisi lain pesantren masih dipersepsikan secara negatif sebagai tempat penanaman nilai-nilai radikalisme. Florian Pohl mengungkapkan bahwa pesantren sebagai lembaga pendidikan Islam diasumsikan sebagai lembaga yang menanamkan radikalisme dan militansi sipil yang negatif. Hal ini dilatarbelakangi oleh realitas bahwa beberapa pelaku terorisme berlatar belakang pendidikan pesantren. ${ }^{7}$ Salah satu contohnya adalah peristiwa bom Bali yang dilakukan oleh sebagian mereka yang pernah belajar di pesantren. ${ }^{8}$

BBC melaporkan hasil investigasinya di Pesantren Al-Mu'min Ngruki. Menurut BBC, radikalisme yang ada di Pesantren Al-Mu'min terlihat dari beberapa alumninya yang terlibat dalam aksi terorisme. Salah satu contohnya adalah Farhan dan Muchsin,alumni Ngruki yangtewas dalam upaya penangkapan oleh Densus 88 tanggal 31 Agustus 2012. Mereka diduga merupakan pelaku serangan tiga pos polisi di Solo pada tanggal 17, 18, dan 30 agustus 2012. ${ }^{9}$ Pada masa 10 tahun sebelumnya (Oktober 2002), Hernianto yang juga salah satu alumni Ngruki, terlibat dalam kasus Bom Bali yang

pada pelaksanaan shalat wajib dan membolehkan pada shalat sunnah. Abu Hanifah, Ahmad, dan ath-Thauri membolehkan bacaan "basmalah"akan tetapi bacaannya tidak keras. Shafi‘i berpendapat bahwa bacaan "basmalah" hendaknya dibaca keras pada 3 shalat waktu (Subuh, Maghrib, dan Isya), dan "basmalah" adalah salah satu bagian ayat dari surat al-Fatihah. Jika basmalah tidak dibaca, maka bacaan suratal-Fatihah tidak sempurna dan akan mengakibatkan shalatnya menjadi tidak sah. Ibnu Rushd, Bidayat al-Mujtahid wa Nihayat al-Muqtasid, (Qahirah: Maktab Shuruq al-Dauliyah, 2011), 103, Sebagaimana diceritakan oleh Salman AlFarisi Basyir, siswa kelas XII Pesantren Darul Qur'an Mulia Bogor, pasca kegiatan PKL di sebuah pesantren di Tangerang pada bulan Nopember 2013.

${ }^{6}$ Azyumardi Azra, "Pesantren Islam Transnasional", Mundzier Suparta, Perubahan Orientasi Pondok Pesantren Salafiyah terhadap Perilaku Keagamaan Masyarakat, (Jakarta: Asta Buana Sejahtera, 2009), xv.

${ }^{7}$ http://www.bbc.co.uk/indonesia/laporan_khusus/2011/10/111011_pesantrendanradik alisme.shtml, (diakses tanggal 3 Februari 2015).

${ }^{8}$ Florian Pohl, "Islamic Education and Civil Society; Reflections on the Pesantren Tradition in Contemporary Indonesia", Chicago Journals, The University of Chicago Press, (2006): 389, www.jstor.org/stable/10.1086/503882, (diakses 27 Maret 2014).

${ }^{9}$ http://www.bbc.com/indonesia/laporan_khusus/2012/10/121012_insidengrukischool. shtml (diakses 19 Januari 2016). 
terjadi pada tanggal 12 Oktober 2002 dengan memfasilitasi rumahnya untuk merencanakan peristiwa tersebut. ${ }^{10}$

Majalah Gatra membuat laporan khusus ketika terjadi ledakan di pesantren Umar bin Khattab di Bima, NTB pada tanggal 11 Juli 2011. Saat terjadi ledakan, aparat kepolisian tidak diizinkan masuk ke dalam pesantren. Aparat diizinkan masuk pesantren dua hari kemudian, dan ditemukan salah seorang guru meninggal dunia di tempat kejadian. Polisi juga menemukan komponen-komponen bahan peledak. Kemudian Gatra melakukan penelusuran bahwa tersangka Abrori (pimpinan pesantren) adalah alumni pesantren al-Muttaqien Jepara. Penelusuran terus dilakukan hingga ada kaitan peristiwa tersebut dengan pesantren al-Mukmin Ngruki dan salah satu Ma'had 'Ali di Solo. ${ }^{11}$

Pada hakikatnya, peran lembaga pendidikan model pesantren sangat besar dalam menanamkan nilai-nilai positif. Niai-nilai moralitas tidak dapat ditanamkan dengan teoritis saja, akan tetapi ia harus diajarkan dengan contoh dan praktik. Praktik kebiasaan yang baik menjadi basis strategis penanaman moral. ${ }^{12}$ Menurut Alex Rodger, sudah seharusnya jika pendidikan agama mampu merefleksikan persoalan keragaman, dengan mentransmisikan nilainilai yang dapat menumbuhkan sikap toleran, terbuka dan kebebasan dalam diri generasi muda. ${ }^{13}$

Jika dilihat dari kategorisasi masyarakat menurut Amitai Etzioni, pesantren tergolong ke dalam masyarakat dengan tipe overmanaged, yaitu masyarakat yang sangat diatur. Masyarakat tipe ini memiliki tingkat pengawasan yang tinggi dengan tingkat konsensus yang rendah. Seorang kiai memiliki otoritas yang sangat tinggi terhadap pesantren. ${ }^{14}$ Adanya keunggulan pesantren yang dapat memadukan antara teori dan praktek kemudian diperkuat dengan kategorisasi Amitai Etzioni semakin mengokohkan signifikansi peluang pesantren sebagai tempat penanaman nilai-nilai toleransi.

\footnotetext{
${ }^{10} \mathrm{http}: / /$ nasional.tempo.co/read/news/2006/02/05/05573468/alumni-ngruki-herniantoseorang-mujahid (diakses 19 Januari 2016).

${ }^{11} \mathrm{http}: / /$ www.gatra.com/hukum-1/781-polisi-cari-pimpinan-ponpes-umar.html. danhttp://www.gatra.com/hukum-1/890-polisi-temukan-bom-aktif-di-bima.html. Lihat kajian tetang pemberitaan tersebut oleh Ken Andari, dkk. Konstruksi Majalah Gatra tentang Radikalisme di Pesantren, Students e-journals, 2012, http://jurnal.unpad.ac.id/ejournal, (diakses tanggal 3 Februari 2015).

${ }^{12}$ Language of morality could not be taught by worth of truth, it had to be taught by example practice not preaching was the basis of moral education. Nuril Furkhan, "The Implementation of Character Education through the School Culture in SMA Negeri 1 Dompu and SMA Negeri Kilo Dompu Regency," An Open Access International Journal, vol. 3, (2014): 22.

${ }^{13}$ Alex R. Rodger, Educational and Faith in Open Society, (Britain: The Handel, 1982), 6.

${ }^{14}$ Anita Inder Singh, Democracy, Ethnic Diversity, and Security in Post-communist Europe, (London: Praeger, 2001), 8.
}

INDO-ISLAMIKA, Volume 5 No. 2 Juli - Desember 2015/1438 | 215 
Gambaran di atas mencerminkan bahwa implementasi toleransi masih menemukan hambatan di tengah masyarakat secara umum.Bagi sebagian umat Islam, toleransi antar mazhab belum sepenuhnya dapat diwujudkan. Begitu pula realitas toleransi terhadap non-Muslim, di mana konflik sosialmewarnaihubungan antar pemeluk agama di Indonesia. Jika hal tersebut dibiarkan, tidak mustahil akan mengikis kohesi sosial yang memiliki nilai historis panjang dan berpotensi membahayakan NKRI. Oleh karena itu diperlukan adanya upaya-upaya penanaman nilai toleransi yang diringi dengan upaya melakukan perlawanan terhadap sikap intoleransi. Peran strategis pesantren dalam menyebarkan nilai-nilai di tengah masyarakat melalui para santrinya meniscayakan bahwa perilaku keislaman yang ada di masyarakat adalah representasi keislaman yang ada di pesantren. Oleh karena itu kajian ini dilakukan untuk memotret tingkat implementasi fikih toleransi di pesantren modern dan pesantren tradisional, baik terkait toleransi internal maupun toleransi eksternal.

\section{KAJIAN TEORITIK}

Kajian terhadap tingkat implementasi fikih toleransi di pesantren dimaksudkan untuk mengetahui realitas fikih toleransi baik internal ataupun eksternal yang ada di pesantren, yang pada akhrinya nilai-nilai tersebut akan di bawa ke tengah masyarakat melalui para alumni pesantren tersebut.

Istilah fikih toleransi yang digunakan dalam kajian ini adalah Istilah "fikih toleransi" yang terdiri dari dua kata yang dipadukan. Kata pertama adalah "fikih" dan kata kedua adalah "toleransi". Kata "fikih" secara etimologis berasal dari kata "faqaha" dalam Bahasa Arab yang berarti; "fahima" (memahami). Sementara kata "al-fiqh" memiliki arti; "al-'ilm bi alshai'i wa al-fahm lahu" (mengetahui tentang sesuatu dan memahaminya dengan baik). Secara umum, ilmu dan pemahaman yang dimaksud dalam kata "fikih" selalu berkaitan dengan ilmu agama dikarenakan keistimewaan ilmu tersebut jika dibandingkan dengan ilmu yang lain. ${ }^{15}$

Menurut al-Subki kata "al-fiqh" memilliki 3 arti yaitu; "mutlaq alfahm" (pemahaman yang sempurna sehingga mutlak diterima), "fahm al'ashyā' al-daqīqah" (pemahaman terhadap sesuatu secara mendalam), dan "fahm ghard al-mutakallim" (pemahaman terhadap tujuan sebenarnya dari pembicara). ${ }^{\text {i6 }}$ Dari ketiga arti tesebut menunjukkan bahwa kandungan dari kata "fikih" meniscayakan pengetahuan terhadap sesuatu secara menyeluruh dan mendalam yang sesuai dengan keinginan subjek pembicara, sehingga

\footnotetext{
${ }^{15}$ Dalam ayat al-Qur'an terdapat kalimat "liyatafaqqahu fi al-din" yang berarti; "untuk mengetahui dan memahami tentang masalah agama". Q.S. Al-Taubah: 122, lihat juga Muhammad ibn Mukrim ibn Manzur, Lisan al- 'Arab, vol. xiii, (Bairut: Dar Sadir, 1994), 522.

${ }^{16 ،}$ Ali 'Abd al-Kafi al-Subki, al-Ibhj, vol. 1, (Bairut: Dar al-Kutub al-'Ilmiyah, t.t.), 28.
}

216 |INDO-ISLAMIKA, Volume 5 No. 2 Juli - Desember 2015/1438 
menghasilkan pemahaman yang mutlak untuk diterima. Secara terminologis kata "al-fiqh" memiliki pengertian "al-'ilm bi al-ahkām al-shar'iyah al'amaliyah al-muktasabah min adillatihā al-tafșiliyah" (ilmu tentang hukum syariat berupa perbuatan yang diambil dari dalil-dalil yang terperinci). ${ }^{17}$

Sedangkan kata "toleransi" dalam Bahasa Arab disebut dengan kata "al-tasāmuḥ". Secara etimologis kata "al-tasāmuh" memiliki akar kata "samaha" yang berarti "jāda" yang artinya; "berbuat baik atau mudah berbagi". Adapun kata "al-tasāmuh" memiliki pengertian "al-tasāhul" (memberikan kemudahan). ${ }^{18}$ Adapun secara terminologis kata "al-tasāmuh" memiliki arti; qabūl al-ākhar (sikap menerima kehadiran yang lain). ${ }^{19}$

Jika dilihat dari makna leksikal Bahasa Inggris, kata "toleransi" secara etimologis berasal dari kata "tolerance" dan "toleration". "Tolerance" memiliki makna; "kesiapan seseorang untuk menerima keyakinan atau kebiasaan orang lain yang berbeda dengannya". Sedangkan makna "toleration" lebih cenderung memiliki makna; "penerimaan terhadap agama orang lain yang berbeda dengan agamanya". Adapun secara terminologis, "toleransi" adalah "sikap membiarkan keyakinan, pikiran, dan perbuatan orang lain walaupun hal itu berbeda dengan pendapatnya, tanpa adanya pemaksaan agar pendapat orang lain berubah, atau upaya menghalangi pelaksanaan pendapat lain yang berbeda." 21 Adapun jika diambil dari kata dasarnya "tolerate", memiliki makna; "to allow to be or to be done without hindrance" (membiarkan sesuatu untuk terjadi atau dikerjakan tanpa merasa kebeeratan). ${ }^{22}$

Dari deskripsi makna kata "al-tasāmuḥ" dan "tolerance" di atas ditemukan kesamaan bahwa kedua kata tersebut mengandung makna; "kesiapan seseorang untuk membiarkan dan menerima kehadiran yang lain yang berbeda dengan dirinya, baik berupa kebiasaan, pemikiran, dan agama". Jika dipadukan makna dari kata "al-fiqh" dan "al-tasāmuh". atau "tolerance" maka menjadi "fiqh al-tasāmuh" atau "fiqh of tolerance" yang dalam Bahasa Indonesia disebut dengan "fikih toleransi". Dengan demikian makna dari "fikih toleransi" adalah satu bentuk kesiapan sikap untuk membiarkan dan

17، Ali 'Abd al-Kafi al-Subki, al-Ibhaj, vol. 1, 28.

${ }^{18}$ Louis Ma'luf, al-Munjid fi al-Lughah, (Bairut: Dar al-Mashriq, 1997), 349.

${ }^{19}$ Ashraf 'Abd al-Wahhab, al-Turath wa al-Taghayyur al-Ijtima'i, (Qahirah: alHay'ah al-Misriyah al-'Ammah: 2006), 90.

${ }^{20}$ Ashraf 'Abd al-Wahhab, al-Turath wa al-Taghayyur al-Ijtima ' $i, 35$.

${ }^{21}$ Ada beberapa makna dari tolerance di antaranya adalah: Pertama, "willingness to accept feelings, habits, or beliefs that are different from your own". Kedua, "the ability to accept, experience, or survive something harmful or unpleasant". http://www.merriamwebster.com/dictionary/tolerance. Lihat juga, Surahman Hidayat, Islam Pluralisme dan Perdamaian, (Jakarta: Fikr, 2008), 40.

${ }^{22}$ Merriam Webster, The Merriam Webster Dictionary, (New York: Merriam Co., 1976), 717 .

INDO-ISLAMIKA, Volume 5 No. 2 Juli - Desember 2015/1438 | 217 
menerima keberadaan yang lain berdasarkan ketentuan yang ada dalam Islam (syari'at Islam).

Istilah "fikih toleransi"sendiri juga telah digunakan beberapa penulis berikut ini. Pertama, 'Abd al-H\} usain Sha'ban dalam bukunya yang berjudul "Fiqh al-Tasamuh\}" yang ditulis pada tahun 1998. Buku tersebut mengungkapkan bahwa yang dimaksud dengan fikih toleransi adalah satu pendekatan dengan menghubungkan antara konsep al-tasamuh\} dengan alShari 'ah al-Islamiyah. ${ }^{23}$ Dengan demikian dapat dipahami bahwa toleransi yang dimaksud dalam fikih toleransi adalah toleransi dalam bingkai aturanaturan dalam Islam. ${ }^{24}$

Kedua, Fahd Șalāh al-'Ijlān yang menyebut fikih toleransi sebagai paradigma yang berada di antara dua paradigma. Paradigma pertama adalah paradigma yang mengharuskan setiap orang mengikuti satu pendapat tertentu (paradigma indoktrinasi), dan menolak berbagai pendapat dan ijtihad yang berbeda. Paradigma kedua adalah paradigma yang membolehkan setiap orang memilih sesuai keinginannya, dari yang paling mudah, paling ringan, paling sesuai dengan hati dan yang paling sesuai dengan zaman mereka. ${ }^{25}$

Adapun terkait tipologi fikih toleransi dalam kajian ini terdiri dari dua tipologi yaitu; fikih toleransi internal dan fikih toleransi eksternal. Kedua tipologi tersebut sejalan dengankonsep "tri kerukunan" yang dikemukakan oleh Alamsjah Ratu Perwira Negara sebagai Menteri agama (1978-1983). ${ }^{26}$ Adapun konsep "tri kerukunan" tersebut adalah: Pertama, kerukunan intern umat beragama (fikih toleransi internal). Kedua kerukunan antar umat beragama (fikih toleransi eksternal). Ketiga, kerukunan antara umat beragama dengan pemerintah. Dari tiga unsur yang terkandung dari konsep tri kerukunan, penelitian ini hanya mengambil dua di antaranya, yaitu kerukunan internal umat beragama dan kerukunan antar umat beragama.

Pembedaan tersebut juga sejalan dengan tipologi yang dikemukakan oleh Pervez Hoodbhoy. Hoodbhoy membedakan sikap terhadap keragaman menjadi dua model yaitu; "inter-religious" (antar beberapa agama yang berbeda) dan intra-religious (dalam satu agama yang sama). Model inter

\footnotetext{
${ }^{23}$ Muh ammad Rawas Qal'ah Ji, Hamid Saduq Qanaibi, Mu 'jam Lughah al-Fuqaha', (Bairut: Dar al-Nafa' is, 1988), 261-262.

${ }^{24 ،}$ Abd al-Husain Sha'ban, Fiqh al-Tasamuh fi al-Fikr al- 'Arabi al-Islami, (Arbil: Dar Aras, 1998), 95-97.

${ }^{25}$ Fahd Salah\} al-'Jjlan, al-Tasamuh\} al-Fiqhi, http://uqu.edu.sa/page/ar/185865 (diakses 5 April 2014).

${ }^{26}$ Masykuri Abdillah, Islam dan Demokrasi: Respons Intelektual Muslim Indonesia terhadap Konsep Demokrasi 1966-1993, 48. Soegeng Hardijanto, et. al., Agama dalam Dialog: Pencerahan, Pendamaian dan Masa Depan, (Jakarta: BPK Gunung Mulia, 2003), 488,lihat juga Weinata Sairin, Kerukunan Umat Beragama: Pilar Utama Kerukunan Berbangsa, (Jakarta: BPK Gunung Mulia, 2006), x.
} 
religious tentu saja sejalan dengan fikih toleransi eksternal, sementara model intra religious sejalan dengan fikih toleransi internal. ${ }^{27}$

Nurcholish Madjid dalam bukunya "Islam Doktrin dan Peradaban", membahas tentang kemajemukan dengan dua sub judul yaitu; iman dan kemajemukan masyarakat intra-umat Islam dan iman dan kemajemukan masyarakat antar umat. Kedua sub judul tersebut memiliki kesamaan dengan istilah internal dan eksternal dalam penelitian ini. ${ }^{28}$

Azyumardi Azra dalam bukunya "Jejak-jejak Jaringan Kaum Muslim" menggunakan istilah toleransi internal dalam menggambarkan sikap penerimaan terhadap keragaman mazhab (furu'iyah) dan aliran pemikiran dalam Islam. Sementara toleransi eksternal dimaksudkan sebagai penerimaan seorang Muslim setelah berinteraksi dengan non-Muslim seperti Yahudi dan Nasrani. $^{29}$

Kategorisasi kelembagaan pesantren merupakan hal yang tidak sederhana jika dikaitkan dengan sistem pendidikan yang ada di pesantren. Ada beberapa alasan yang memunculkan kesulitan tersebut, di antaranya: Pertama, fungsi atau peran pesantren tidak terlepas dari perkembangan komunitas yang ada di sekelilingnya. Kedua, pesanten dalam skala tertentu masih bergantung kepada karakteristik pemilik, pendiri, dan kiai. Sehingga kadangkala pesantren tidak mengikuti standar model pendidikan yang sudah ditentukan oleh pemerintah. Menurut Angel Rabasa, hal ini terjadi karena memang sebagian pesantren di Indonesia dijalankan bahkan dimiliki oleh seorang guru yang ahli dalam bidang agama. ${ }^{30}$ Ketiga, kegiatan pesantren memang tidak tergantung kepada program atau visi pemerintah akan tetapi lebih didasarkan kepada nilai-nilai Islam. ${ }^{31}$

Di antara kategorisasi pesantren yang umum dan digunakan dalam penelitian ini adalah pembedaan pesantren menjadi 2 model yaitu; pesantren Khalaf (modern) dan pesantren Salaf (tradisional). Pesantren modern adalah pesantren yang menggunakan sistem pendidikan konvensional dan meninggalkan konsep pendidikan tradisional. Sementara pesantren tradisional adalah pesantren yang tetap menjaga sistem pendidikan tradisional, dan menjadikan masjid sebagai pusat kegiatan pembelajaran. Buku yang biasa

\footnotetext{
${ }^{27}$ Pervez Hoodbhoy, "Islam and Pluralism in the Modern Muslim State", Islam and Pluralism, (April 2011): 1, (diakses 25 Oktober 2015).

${ }^{28}$ Nurcholish Madjid, "Iman dan Kemajemukan Masyarakat Antar Umat Beragama", Islam Doktrin dan Peradaban, (Jakarta: Paramadina, 1999), 149.

${ }^{29}$ Azyumardi Azra, Jejak-jejak Jaringan Kaum Muslim, (Jakarta: Hikmah, 2007), 61.

${ }^{30}$ Angel Rabasa, "Islamic Education in Southeast Asia", in: Hillel Fradkin, Husain Haqqani, and Eric Brown (eds.), Current Trends in Islamic Ideology, vol. 2, (Washington: Hudson Institute, 2005), 101-102.

${ }^{31}$ Suprayetno Wagiman, The Modernization of the Pesantren's Educational System to Meet the Needs of Indonesia Communities, (Montreal: McGill University, 1997), 76.
} 


\section{Abdul Ghoni}

digunakan di pesantren tradisional adalah kitab kuning yang diambil dari warna kertas buku tersebut. ${ }^{32}$

Pembedaan antara pesantren tradisional dan pesantren modern terusmenerus mengalami perubahan. Menurut Mujamil Qomar kedua istilah tersebut terus mengalami perubahan seiring dengan perubahan waktu dan perkembangan sistem pendidikan. Sehingga batas-batas pembeda antara pesantren tradisional dan modern membutuhkan penegasan kembali. ${ }^{33}$

Dalam penelitian ini penulis menggunakan kategorisasi pesantren tradisional dan modern dengan beberapa penyempurnaan karakteristik. Karakteristik pertama adalah berdasarkan kurikulum fikih. Pesantren tradisional mengajarkan fikih dengan mazhab tertentu yang dijadikan sebagai pegangan (homogenitas). Sementara pesantren modern menjadikan buku fikih dengan pendekatan perbandingan mazhab sebagai buku pegangan yang juga diberikan kepada para santrinya sehingga mereka dapat mengkajinya lebih mendalam secara mandiri dan dapat menggunakannya sebagai pegangan dalam berpendapat.

Karakteristik kedua adalah terkait dengan kebijakan aturan pesantren. Pesantren tradisional memiliki kebijakan untuk mengizinkan santri tinggal di rumahnya masing-masing sehingga santri hanya datang pada saat kegiatan belajar berlangsung. Ada pula pesantren tradisional yang mengizinkan santri untuk mengikuti kegiatan pendidikan formal di luar pesantren. Sementara pesantren modern pada umumnya mengharuskan santri untuk tinggal dan mengikuti kegiatan pendidikan formal di dalam pesantren. Hal ini dalam kategorisasi Zamakhsyari Dhofier disebut dengan santri mukim dan santri kalong. ${ }^{34}$ Pada perkembangannya santri mukim lebih cenderung menjadi karakteristik pesantren modern dan kategori santri kalong atau santri yang terpisah program pendidikannya antara program pesantren dan program formal lebih cenderung ke pesantren tradisional.

Karakteristik ketiga terkait dengan prinsip keterbukaan pesantren. Pesantren tradisional memiliki kecenderungan untuk mengakomodir model pemikiran atau kebiasaan kelompok tertentu dalam Islam, sementara pesantren modern pada umumnya bersifat terbuka dengan berbagai kelompok dalam Islam. ${ }^{35}$

\footnotetext{
${ }^{32}$ Ali Maksum, Model Pendidikan Toleransi di Pesantren Modern dan Salaf, (2013): 3, eprints.uinsby.ac.id/121/1/Executive\%20Summar\%20ali\%20maksum.pdf (diakses 6 Oktober 2015). Lihat juga Mujamil Qomal Pesantren; dari Transformasi Metodologi Menuju Demokratisasi Institusi, (Jakarta: Erlangga, 2007), 142.

${ }^{33}$ Mujamil Qomar, Pesantren; dari Transformasi Metodologi Menuju Demokratisasi Institusi, 142.

${ }^{34}$ ZamakhsyariDhofier, Tradisi Pesantren: Studi Pandangan Hidup Kiai dan Visinya Mengenai Masa Depan Indonesia, 89.

${ }^{35}$ Salah satu contoh sederhana adalah dengan slogan yang digunakan oleh pesantren modern yang berbunyi; "berdiri di atas dan untuk semua golongan". Hal ini menyiratkan kesiapan pesantren untuk bersikap terbuka terhadap keragaman sesama umat Islam sendiri.
} 
Dalam penelitian ini penulis menjadikan 5 pesantren sebagai objek penelitian. Pesantren Ibnu Abbas, Pesantren Rafah dan Pesantren Darunnajah merepresentasikan pesantren modern, sementara Pesantren Al-Ishlah dan Pesantren Babussalam merepresentasikan pesantren tradisional. Pesantren Ibnu Abbas, Pesantren Darunnajah, dan Pesantren Rafah adalah pesantren yang termasuk dalam kategorisasi pesantren modern di mana para santri diajarkan keragaman mazhab dalam fikih, kemudian mereka juga diwajibkan untuk tinggal di dalam pesantren, serta sikap keterbukaan pesantren terhadap berbagai kelompok dalam Islam.

Sementara Pesantren Al-Ishlah dan Pesantren Babussalam termasuk dalam kategori pesantren tradisional dengan beberapa karakteristik; pesantren tidak mengajarkan keragaman mazhab fikih kepada para santrinya, memperbolehkan santrinya untuk tinggal di rumah masing-masing, dan tidak secara eksplisit menyatakan terbuka untuk semua komunitas Muslim di Indonesia.

\section{HASIL DAN PEMBAHASAN}

Pesantren sebagai agen perubahan, ${ }^{36}$ tentu saja perlu mengetahui sejauh mana nilai-nilai yang ideal termasuk toleransi, diterapkan di dalamnya. Dengan mengetahui standar toleransi yang ada di pesantren tersebut, maka berbagai langkah dapat dilakukan sebagai tindak lanjutnya. Di sebuah pesantren yang kadar toleransinya baik, maka dapat dijadikan sebagai percontohan bagi pesantren lainnya. Sebaliknya, jika nilai toleransi tidak tertanam dengan baik di kalangan santrinya, dapat dilakukan upaya perbaikan pada masa-masa berikutnya.

Penelitian ini dilakukan dengan tujuan untuk mengukurstandar toleransi yang ada di pesantren, dengan mengambil jumlah responden $(\mathrm{N})$ sebanyak 287 santri yang sedang mengikuti program pembelajaran di 5 pesantren di Jawa.

Pesantren Darunnajah dan Pesantren Rafah keduanya menggunakan slogan tersebut. Wawancara dengan Kepala Madrasah Tsanawiyah Darunnajah, Muchamad Hasan Darojat pada tanggal 27 Januari 2015, dan Kepala Madrasah Tsanawiyah Rafah, Nanang Alfan Amrullah pada tanggal 31 Januari 2015.

${ }^{36}$ Said Romadlan, "Rekayasa Sosial Adopsi Teknologi Komunikasi di Kalangan Pondok Pesantren Muhammadiyah", Jurnal Lemlit Uhamka, (2013): 84, http://www.seminaruhamka.net/uploads/3/2/8/0/3280177/maqrav2n2_2013_11_said-hal.pdf, (diakses tanggal 30 Januari 2015).

INDO-ISLAMIKA, Volume 5 No. 2 Juli - Desember 2015/1438 | 221 
Tabel 1. Deskripsi Variabel Toleransi

\begin{tabular}{cccccc}
\hline & $\mathrm{N}$ & Minimum & Maximum & Mean & Std. Deviation \\
\hline Fikih Toleransi & 287 & 26 & 45 & 37.21 & 3.926 \\
\hline $\begin{array}{c}\text { Valid N } \\
\text { (listwise) }\end{array}$ & 287 & & & & \\
\hline
\end{tabular}

Tabel di atas menunjukkan beberapa hal sebagai berikut; skor pertengahan Toleransi (median) sebesar 37, skor rata-rata toleransi (mean) adalah 37,21, dan standar deviasi sebesar 3,926. Adapun nilai minimum Toleransi santri pada penelitian ini adalah 26 , dan nilai maksimumnya adalah 45.

Dari angka mean sebesar 37,21 dengan standar deviasi 3,926 maka skor tinggi, skor sedang, dan skor rendah dapat ditentukan. Adapun hasilnya adalah; skor tinggi sebesar $>41$, skor sedang antara 34-40, dan skor rendah adalah antara $<33$.

Dari kategorisasi tersebut dapat dilihat tingkat toleransi dari 287 santri yang menjadi responden penelitian ini, sebagaimana tercantum pada tabel berikut ini:

Tabel 2. Kategorisasi Tingkat Toleransi

\begin{tabular}{|c|c|c|}
\hline Tinggi & Sedang & Rendah \\
\hline 68 santri & 163 santri & 56 santri \\
\hline $23,7 \%$ & $56,8 \%$ & $19,5 \%$ \\
\hline
\end{tabular}

Dengan demikian dari jumlah keseluruhan 287 orang santri yang menjadi responden, santri yang memiliki tingkat toleransi pada level tinggi adalah sebanyak 68 santri atau 23,7\% dari jumlah keseluruhan. Sementara santri yang memiliki kualifikasi toleransi tingkat sedang sebanyak 163 santri, setara dengan 56,8\% seluruhnya. Adapun santri dengan tingkat toleransi rendah berjumlah 26 orang, dengan persentase sebesar $19,5 \%{ }^{37}$

Data penelitian di atas menunjukkan bahwa lebih dari $50 \%$ santri memiliki tingkat toleransi yang sedang, yang berarti rata-rata pesantren cukup mampu menanamkan nilai toleransi kepada santrinya. Tingkat toleransi tersebut tidak dipengaruhi secara langung oleh model dan karakteristik pesantren tersebut. Namun demikian tingkat toleransi yang dimaksud masih bersifat umum dan belum dibedakan antara toleransi internal dan eksternal.

Di samping itu perbedaaan asal pesantren terkait dengan tingkat toleransi tidak memiliki pengaruh yang signifikan, dengan demikian tidak ada

\footnotetext{
${ }^{37}$ Lihat lampiran "Frekuensi Variabel Toleransi”.
} 
perbedaan yang patut disoroti lebih lanjut terkait dengan tingkat implementasi toleransi secara umum di masing-masing pesantren. Hasil penelitian kuantitatif membuktikan bahwa secara umum seluruh pesantren yang menjadi objek penelitian ini memiliki kemampuan untuk menanamkan nilai toleransi kepada para santrinya. Berdasarkan hasil uji beda dalam penelitian ini, disimpulkan bahwa perbedaan toleransi antara satu pesantren dengan pesantren lain tidak signifikan perbedaannya. Hal tersebut diketahui dari skor sign.sebesar $0,164>0,05$ yang berarti tidak signifikan. ${ }^{38}$

Temuan di atas semakin menguatkan pendapat bahwa pesantren dengan berbagai tipologi dan modelnya sudah mampu menanamkan nilainilai toleransi kepada santrinya. Realitas inilah yang sesuai dengan harapan dan cita-cita Alex Rodger, bahwa lembaga pendidikan keagamaan harus mampu menanamkan adanya keragaman, menumbuhkan sikap toleransi pada peserta didiknya dan melahirkan sikap keterbukaan pada diri generasi muda. ${ }^{39}$ Hal tersebut juga menunjukkan bahwa pesantren telah mengalami perubahan dan cenderung inklusif sehingga mampu berinteraksi secara aktif dengan sekitarnya. Perubahan yang dialami pesantren sejalan dengan perubahan sosial, politik dan budaya di luar pesantren. ${ }^{40}$

Hasil penelitian yang menunjukkan bahwa rata-rata pesantren sudah mampu menanamkan nilai-nilai toleransi, juga sejalan dengan hasil penelitian kualitatif yang dilakukan oleh Ali Maksum terhadap alumni pesantren Gontor dan Tebuireng. Menurut Ali Maksum, kedua pesantren walaupun memiliki karakteristik yang berbeda, namun mampu membiasakan para santrinya dengan nilai toleransi. Penanaman nilai toleransi di pesantren modern seperti Gontor, di antaranya dilakukan dengan cara menempatkan santri dalam satu asrama, dengan santri lain yang berasal dari berbagai daerah, dan penempatan tersebut akan diubah setiap semester atau setiap tahun. Sementara pada pesantren salaf seperti Tebuireng, penanaman nilai toleransi dilakukan dengan 2 hal yaitu; pertama dengan dimasukkannya kurikulum kewarganegaraan dalam pembelajaran pesantren dan gaya kepemimpinan kiai yang lebih demokratis. ${ }^{41}$

Arus perubahan yang tengah menjadi fenomena dalam lingkungan pesantren juga diungkapkan oleh Danar Widayanta dan Miftahuddin. Dalam hasil penelitiannya tentang pesantren Wahid Hasyim Sleman Yogyakarta,

${ }^{38}$ Lihat lampiran "Analisis Uji Beda Pesantren dan Toleransi (Uji One Way Anova)".

${ }^{39}$ Alex R. Rodger, Educational and Faith in Open Society, (Britain: The Handel, 1982), 61

${ }^{40}$ Jeffrey A, Ritchey and Nurhaya Muchtar, Indonesian Pesantrenand Community Social Change: Moderate Islam's Use of Media and Technology for Nonformal, Community, (2014): 422, http://www.adulterc.org (diakses tanggal 30 Januari 2015).

${ }^{41}$ Ali Maksum, Model Pendidikan Toleransi di Pesantren Modern dan Salaf, (2013): 14-15, http://eprints.uinsby.ac.id/121/1 (diakses tanggal 19 Desember 2014).

INDO-ISLAMIKA, Volume 5 No. 2 Juli - Desember 2015/1438 | 223 
diketahui bahwa pesantren tersebut pada awalnya adalah pesantren Salaf (tradisional) akan tetapi kemudian mengalami transformasi menjadi pesantren Khalaf (modern) ditandai dengan model cara berpikir yang ditanamkan pesantren tersebut kepada santrinya. Perubahan model pemikiran terjadi dari model berfikir tekstual (qauli) menjadi model berfikir metodologis (manhajī). Di samping itu, pesantren Wahid Hasyim juga secara internal memberikan stimulus dengan perubahan gaya kepemimpinan kiai yang sebelumnya cenderung individual dan tertutup menjadi kepemimpinan kolektif. ${ }^{42}$ Tentu saja perubahan baik pada model pemikiran santri dan model kepemimpinan menunjukkan adanya toleransi terhadap model yang lain, bahkan dari toleransi itu membawa pesantren pada proses perubahan yang besar.

Hasil penelitian Ali Maksum, yang menyebutkan bahwa pendidikan kewarganegaraan dalam kurikulum pesantren memberikan kontribusi pada lahirnya toleransi di pesantren salaf, sejalan dengan hasil penelitian yang dilakukan oleh Steven E. Finkel dan Amy Erica Smith di Kenya pada tahun 2000. Hasil penelitian Finkel dan Smith menyebutkan bahwa pendidikan kewarganegaraan (civic education) memiliki efek positif dalam menumbuhkan nilai-nilai demokratis seperti; toleransi, dan kepercayaan terhadap institusi. Pendidikan kewarganegaraan juga menjadi informasi bagi warga negara agar dapat terlibat secara aktif dalam diskusi dan wacana politik, sekaligus menjadi kesempatan pelatihan bagi mereka. ${ }^{43}$

Bryony Louise Hoskins, dkk dalam penelitiannya yang membandingkan tingkat kompetensi kewargaan di kalangan pemuda di Eropa, menyimpulkan bahwa civic education dapat memberikan pengaruh positif terhadap pemuda. Menurut Hoskins, ada 2 hal yang dapat dilakukan dalam hal ini, yaitu: Pertama, melalui kurikulum yang meningkatkan kemampuan kognitif dan afektif sekaligus. Hal ini mengingat toleransi tidak cukup hanya untuk diketahui akan tetapi nilai tersebut perlu diterapkan dalam kehidupan. Kedua, melalui pengalaman pembelajaran di ruang belajar terbuka. ${ }^{44}$ Judith Torney-Purta menguatkan pentingnya ruang belajar terbuka dalam penanaman nilai toleransi. Menurutnya pada hampir 2/3 negara-negara

${ }^{42}$ Danar Widayanta, Miftahuddin, "Dinamika Pemikiran Santri: Studi atas Pengaruh Kepemimpinan di Pesantren Wahid Hasyim Sleman (1998-2005), (2007): 8, (diakses 20 Maret 2015).

${ }^{43}$ Steven E. Finkel dan Amy Erica Smith, "Civic Education, Political Discussion, and the Social Transmission of Democratic Knowledge and Values in a New Democracy: Kenya 2000", American Journal of Political Sciece, vol. 55, no. 2 (April 2011): 418, www.jstor.org/stable/23025060 (diakses tanggal 19 Desember 2014).

${ }^{44}$ Bryony Louise Hoskins, et. al., "Comparing Civic Competence among European Youth: Composite and Domain-Specific Indicators Using IEA Civic Education Study Data: Comparative Education Review", vol. 55, no. 1 (Februari 2011): 82-83, 105, Chicago Journals, http://www.jstor.org/stable/10.1086/656620 (diakses tanggal 19 Desember 2014). 
di seluruh dunia menjadikan hal tersebut sebagai media pokok pembiasaan toleransi. Hal ini sangat positif mengingat di dalam pembelajaran ruang kelas terbuka akan muncul iklim dan sikap saling menghormati antara guru dan siswa atau antar sesama siswa itu sendiri. ${ }^{45}$

Namun demikian, jika ditelusuri lebih lanjut melalui dua tipologi toleransi dalam penelitian ini yaitu; toleransi internal dan toleransi eksternal, maka hasilnya menunjukkan perbedaan yang signifikan sebagaimana digambarkan pada rangkaian tabel berikut ini.

Tabel 3. Deskripsi Variabel Toleransi Internal

\begin{tabular}{|c|c|c|c|c|c|}
\hline & $\mathrm{N}$ & Minimum & Maximum & Mean & Std. Deviation \\
\hline $\begin{array}{c}\text { Fikih_Toleransi } \\
\text { Internal }\end{array}$ & 287 & 3 & 10 & 8,72 & 1,143 \\
\hline $\begin{array}{l}\text { Valid N } \\
\text { (listwise) }\end{array}$ & 287 & & & & \\
\hline
\end{tabular}

Dari data tabel 3 di atas dapat disimpulkan bahwa pada toleransi internal, nilai rata-rata toleransi adalah 8,72 , dengan nilai minimum dengan skor 3 dan nilai maksimum dengan skor 10. Adapun standar deviasinya adalah 1,143. Dari tabel di atas kemudian dibuat kategorisasi level Toleransi internal seperti dijelaskan pada tabel berikutnya.

Dari angka mean sebesar 8,72 dengan standar deviasi 1,143 maka skor tinggi, skor sedang, dan skor rendah tingkat toleransi dapat ditentukan. Adapun hasilnya adalah; skor tinggi sebesar $>10$, skor sedang antara $8-9$, dan skor rendah adalah antara $<7$.

Dari analisis uji beda pesantren dan toleransi internal, terlihat angka signifikansinya sebesar 0,001 yang berarti lebih kecil dari 0,05 maka Ho diterima yang berarti signifikan. Dengan demikian dari angka tersebut dapat disimpulkan bahwa perbedaan pesantren berpengaruh signifikan terhadap tingkat toleransi internal, sebagaimana tergambar pada tabel7 berikut ini.

\footnotetext{
${ }^{45}$ Judith Torney-Purta, "Patterns in the Civic Knowledge, Engagement, and Attitudes of European Adolescents: The IEA Civic Education Study", European Journal of Education, vol. 37 , no. 2, (2002): 135 .
}

INDO-ISLAMIKA, Volume 5 No. 2 Juli - Desember 2015/1438 | 225 
Abdul Ghoni

Tabel 4. Toleransi Internal

Toleransi Internal

\begin{tabular}{lccccc}
\hline & $\begin{array}{c}\text { Sum of } \\
\text { Squares }\end{array}$ & Df & Mean Square & F & Sig. \\
\hline $\begin{array}{l}\text { Between } \\
\text { Groups }\end{array}$ & 23.244 & 4 & 5.811 & 4.676 & .001 \\
\hline Within Groups & 350.456 & 282 & 1.243 & & \\
\hline Total & 373.700 & 286 & & & \\
\hline
\end{tabular}

Adapun dari analisa post hoc dapat dilihat rata-rata skor toleransi internal dari 5 pesantren yang diteliti pada tabel berikut ini.

Tabel 5.

Tukey HSD ${ }^{\mathrm{a}, \mathrm{b}}$

Level Toleransi_Internal

\begin{tabular}{l|c|c|c|c}
\hline \multirow{2}{*}{ Pesantren } & \multirow{2}{*}{$\mathrm{N}$} & \multicolumn{3}{|c}{ Subset for alpha $=0.05$} \\
\cline { 3 - 5 } & & 1 & 2 & 3 \\
\hline Pesantren Babussalam & 59 & 8.32 & & \\
\hline Pesantren Al-Ishlah & 48 & 8.48 & 8.48 & \\
\hline Pesantren Rafah & 68 & 8.74 & 8.74 & 8.74 \\
\hline Pesantren Darunnajah & 69 & & 8.97 & 8.97 \\
\hline Pesantren Ibnu Abbas & 43 & & & 9.12 \\
\hline
\end{tabular}

Tabel di atas menunjukkan skor mean masing-masing pesantren. Adapun hasilnya secara berturut-turut adalah sebagai berikut: Pertama, Pesantren Ibnu Abbas dengan skor mean tertinggi sebesar 9,12. Kedua, Pesantren Darunnajah dengan skor mean toleransi internal sebesar 8,97. Ketiga, Pesantren Rafah dengan mean sebesar 8,74. Keempat, Pesantren AlIshlah dengan skor mean sebesar 8,48. Kelima, Pesantren Babussalam dengan skor mean sebesar 8,32.

Fenomena perbedaan tingkat toleransi internal antar pesantren yang signifikan, juga menyiratkan bahwa penanaman toleransi internal atau toleransi antar sesama Muslim dalam pesantren masih belum merata dan seimbang. Ada pesantren_dalam penelitian ini_yang memiliki kemampuan untuk menanamkan toleransi internal kepada para santrinya cukup baik dan ada pesantren yang tidak cukup mampu menanamkan nilai toleransi internal. ${ }^{46}$

${ }^{46}$ Perbedaan yang signifikan antara satu pesantren dengan pesantren lain dalam penelitian ini menunjukkan masih adanya pesantren yang tingkat toleransi internalnya sangat rendah. Hal ini akan berdampak pada problem sosial ketika santri kembali ke masyarakat. Maka pengenalan keragaman akan menjadi sumber solidaritas dan sarana untuk membangun kebersamaan sesama Muslim. Islamic Conference of Culture Ministers, Islamic Declaration on

Cultural

Diversity,

(2004):

9 ,

226 |INDO-ISLAMIKA, Volume 5 No. 2 Juli - Desember 2015/1438 
Sikap toleran terhadap perbedaan mazhab atau perbedaan dalam masalah furu'iyah belum sempurna dijabarkan secara komprehensif di pesantren tertentu. Penelitian ini juga memberikan makna bahwa upaya penanaman toleransi internal harus terus diupayakan dari waktu ke waktu. Jika pola penanaman toleransi internal di pesantren belum maksimal, tentu saja akan mewarisi keadaan yang sama di tengah masyarakat Muslim. Kenyataan ini sejalan dengan masih rentannya konflik sosial yang dilator belakangi oleh perbedaan yang tidak prinsipil sesama umat Islam. ${ }^{47}$

Hasil penelitian kuantitatif ini juga didukung oleh penelusuran lebih lanjut yang bersifat kualitatif. Dari 5 pesantren yang menjadi kajian penelitian ini, secara berturut-turut 3 pesantren pertama yang memiliki tingkat toleransi tinggi adalah; Pesantren Ibnu Abbas, Pesantren Darunnajah, dan Pesantren Rafah. Sementara 2 pesantren lainnya pada peringkat 4 dan 5 toleransi internal yaitu; Pesantren Al-Ishlah dan Babussalam.

Pesantren Ibnu Abbas dengan tingkat toleransi internal tertinggi dari 5 pesantren yang menjadi objek penelitian ini, sangat selektif dan efektif dalam memberikan pengenalan keragaman mazhab. Upaya selektif Pesantren Ibnu Abbas dilakukan dengan cara lebih menekankan pembelajaran pada masalahmasalah fikih tertentu yang ada dan terjadi di tengah masyarakat. Pesantren Ibnu Abbas tidak terlalu dalam mengajarkan secara teoritis masalah-masalah fikih yang tidak relevan dengan kontek sosial kultural masyarakat Indonesia. Cara pengajaran keragaman mazhab yang dijalankan Pesantren Ibnu Abbas memiliki hasil yang lebih efektif, di mana para santri dapat menguasai secara komprehensif masalah fikih yang diajarkan. ${ }^{48}$

Di samping itu, tingginya tingkat fikih toleransi internal para santri dikuatkan dengan hasil wawancara penulis dengan guru bidang studi fikih yang mengajar di Pesantren Ibnu Abbas. Dari hasil wawancara diketahui bahwa pesantren pada awalnya sudah terlebih dahulu membekali santri dengan materi fikih ibadah secara utuh dan komprehensif. Hal ini ditanamkan kepada santri agar mereka memahami bagaimana tata cara melaksanakan ibadah yang benar, seperti; pelaksanaan ibadah shalat, zakat, puasa, dan haji. Pemahaman santri tentang ibadah dilandasi oleh dalil-dalil yang kuat beserta tuntunan yang ada di dalamnya. ${ }^{49}$ Adapun buku pegangan

http://www.usc.edu/schools/college/crcc/private/cmje/heritage/Islamic_Cultural_Diversity.pdf ., (diakses 21 Oktober 2015).

${ }^{47}$ United States Institute for Peace (USIP), "Ijtihad: Reinterpreting Islamic Principles for the Twenty-First Century", Special Report, Wahington, (August, 2004): 1-2, http://www.usip.org/sites/default /files/sr125.pdf (diakses 21 Oktober 21,2015).

${ }^{48}$ Hasil wawancara dengan Tukimin Ahmad Fathuddin, Kepala SMAIT Ibnu Abbas Klaten pada tanggal 20 Februari 2015 dan Umar al-Faruq, Guru bidang studi Fikih di SMAIT Ibnu Abbas Klaten pada tanggal 21 Februari 2015.

${ }^{49}$ Wawancara dengan Umar al-Faruq, Guru bidang studi Fikih di SMAIT Ibnu Abbas Klaten pada tanggal 21 Februari 2015.

INDO-ISLAMIKA, Volume 5 No. 2 Juli - Desember 2015/1438 | 227 
fikih yang digunakan di Pesantren Ibnu Abbas adalah buku Fiqh al-Sunnah karya al-Sayyid Sābiq. Buku tersebut adalah buku fikih yang dikarang pada era modern, sehingga muatannya lebih kontekstual dibanding fikih-fikih terdahulu. Hal tersebut ditandai dengan metode Al-Sayyid Sābiq dalam membahas fikih dengan menggunakan pendekatan yang beragam. Di antara pendekatan yang digunakan adalah dengan perbandingan mazhab. Pendekatan seperti ini memiliki kesamaan dengan metode yang digunakan oleh Ibnu Rushd dalam bukunya Bidāyat al-Mujtahid. Salah satu contohnya adalah pada pembahasan hukum shalat setelah Shalat Subuh dan Ashar. ${ }^{50}$

Di samping itu al-Sayyid Sābiq tidak semata-mata membahas fikih dengan pendekatan normatif, akan tetapi beliau memasukkan beberapa pendekatan seperti pendekatan sosiologis dalam kajian fikihnya. Misalnya, pada pembahasan tentang masalah pernikahan, beliau mengemukakan pendapatnya sendiri bahwa konflik pernikahan atau konflik rumah tangga lebih banyak terjadi pada masyarakat perkotaan daripada masyarakat pedesaan. Hal ini disebabkan oleh realitas keadaan masyarakat pedesaan yang lebih sedikit dalam penggunaan mahar, sementara masyarakat perkotaan membutuhkan pembelanjaan mahar yang lebih banyak. ${ }^{51}$ Hal ini menyebabkan seorang laki-laki perlu melakukan persiapan yang cukup dan harus berhati-hati dalam memilih calon pasangan hidupnya. ${ }^{52}$

Pesantren yang mengajarkan Fiqh al-Sunnah memberikan pengaruh terhadap sikap keterbukaan santrinya akan hal-hal baru dalam kaitannya dengan fikih. Semakin nyata bahwa dengan pendekatan non-agama (seperti sosiologi), maka produk ijtihādakan semakin beragam dan kontekstual. Dengan penanaman fikih seperti ini maka para santri tidak hanya mengenal keragaman mazhabakan tetapi juga mengenal keragaman pendekatan sehingga memiliki hasil ijtihād berbeda.

Sementara itu, Pesantren Darunnajah adalah pesantren dengan tingkat fikih toleransi internal kedua setelah Pesantren Ibnu Abbas. Dari sisi kurikulum pesantren, secara umum Darunnajah mengacu ke Pesantren Gontor dengan beberapa penyesuaian terhadap kebutuhan riil pesantren. Adapun mata pelajaran yang terkait langsung dengan toleransi internal adalah Fikih dengan buku peganganBidāyat al-Mujathid dan Fiqh al-Sunnah. Penggunaan kedua buku fikih tersebut dikarenakan pendekatan keragaman mazhab di dalamnya.

${ }^{50}$ Al-Sayyid Sābiq, Fiqh al-Sunnah, vol. 1, (Lubnān: Dār al-Fikr, 1983), 91-92.

${ }^{51}$ Seorang laki-laki diwajibkan membayar mahar ketika hendak menikahi seorang perempuan. Kata "ujür" dalam surat al-Nisâ' ayat 25 memiliki arti; mahar. Para ulama bersepakat bahwa besarnya mahar tidak ditentukan ukurannya, namun demikian Rasulullah memerintahkan untuk memberikan kemudahan dalam besaran mahar yang diminta. Q.S. AlNisā': 25. Lihat juga Mạ̣mud 'Ukāshah, , Huqūq al-Zaujah fỉ al-Islām, (Qāhirah: alAkadimiyah al-Hadithah li al-Kitāb al-Jāmi `i, 2006), 61.

${ }^{52}$ Al-Sayyid Sābiq, Fiqh al-Sunnah, vol. 3, 12. 
Pesantren Darunnajah dan Rafah memiliki kesamaan cara penanaman fikih toleransi internal yaitu dengan mengajarkan fikih dengan pengenalan keragaman mazhab dengan buku pegangan Bidāyat al-Mujathid. Dengan demikian pesantren memperkenalkan keragaman bukan hanya dalam masalah fikih yang ada di tengah masyarakat, akan tetapi juga dalam masalahmasalah yang lain yang hampir tidak nyata dibutuhkan dalam kehidupan sosial agama saat ini.

Dari hasil wawancara penulis terhadap salah seorang santri di Pesantren Rafah, Muhammad Fazri Madana, menurutnya bahwa dengan mempelajari Bidāyat al-Mujtahid, timbul kesadaran pada dirinya sebagai santri, untuk mengapresiasi perbedaan fikih dan tidak memaksakan pendapatnya sendiri kepada masyarakat. Dari situ pula ia mengetahui ternyata kebiasaan yang berbeda-beda di tengah masyarakat juga memiliki sandaran atau dalil yang menguatkannya. ${ }^{53}$

Abū Ashrāf menuliskan beberapa manfaat dari pengenalan terhadap keragaman fikih, yaitu: Pertama, pengetahuan akan keragaman dengan berbagai kemungkinannya, akan melahirkan kesimpulan yang komprehensif dari berbagai pandangan, sehingga terjadi perkembangan yang semakin pesat. Kedua, pengenalan keragaman adalah bagian dari proses pembelajaran dan pengalaman akal untuk lebih produktif dalam menghasilkan pendapat. Ketiga, pengenalan keragaman akan mendorong seorang Muslim untuk lebih mendalami lagi tentang fikih dan kaedah-kaedah dasarnya. Keempat, pengenalan keragaman akan mendorong upaya pengkajian lebih dalam, dengan merujuk perbedaan pendapat kepada al-Qur'an dan Hadits. Kelima, pengenalan keragaman akan melahirkan kreativitas sehingga pemecahan terhadap permasalahan terus berjalan dengan baik. Keenam, pengenalan keragaman akan melahirkan tarjịh sebagai upaya menetapkan salah satu pendapat yang memiliki nilai kebenaran yang lebih baik. ${ }^{54}$

Pengenalan dan pembiasaan akan keragaman, menurut David Livermore adalah bagian dari indikator kecerdasan kultural (cultural intelligence) pada diri seseorang. Kecerdasan kultural adalah kemampuan yang memudahkan seseorang untuk berinteraksi dengan keragaman dari berbagai konteks budaya. Seseorang yang memiliki kecerdasan kultural yang baik juga memiliki kemampuan untuk mengintegrasikan dan menghargai

\footnotetext{
${ }^{53}$ Hasil wawancara dengan Muhammad Fazri Madana, santri asal Bogor yang pernah memimpin organisasi santri di Pesantren Rafah periode 2013-2014. Wawancara dilakukan pada tanggal 31 Januari 2015.

${ }^{54} \mathrm{Abu \overline { }}$ Ashrāf ,al-Ikhtilāfāt al-Fiqhīyah wa Atharuhā fī Takwīn al-Malakah wa Tanmiyyatuhā, (2012), http://www.hadaik.com/vb/showthread.php?t=7390 (diakses 25 Februari 2015).
}

INDO-ISLAMIKA, Volume 5 No. 2 Juli - Desember 2015/1438 | 229 
perbedaan dalam keragaman. Baginya perbedaan adalah kenyataan yang perlu diambil manfaatnya. ${ }^{55}$

Sementara 2 pesantren dengan fikih toleransi internal rendah adalah Pesantren Al-Ishlah dan Pesantren Babussalam. Kedua pesantren ini menjadikan fikih mazhab tertentu sebagai rujukannya. Tentu saja hal ini akan sangat mempengaruhi sikap santri dalam menghadapi keragaman. Model pesantren seperti ini dapat disebut sebagai pesantren Mazhabi yang berpengaruh pada corak pemikiran yang berkembang di pesantren. ${ }^{56}$

Pesantren Al-Ishlah hanya mengajarkan fikih mazhab Shäfīi dan tidak menggunakan buku rujukan fikih yang memuat keragaman mazhab. Adapun di Pesantren Babussalam, pendekatan pembelajaran fikih yang digunakan tidak merujuk ke salah satu buku fikih tertentu akan tetapi merujuk langsung kepada Al-Qur'an dan Hadits, yang kemudian langsung disimpulkan oleh kiai atau guru sesuai dengan pilihan ijtihad fikihnya. Sehingga, walaupun pesantren sebenarnya memiliki visi untuk menanamkan fikih lintas mazhab, akan tetapi santri tidak mengenal keragaman fikih tersebut secara komprehensif dan tidak dapat mengkajinya lebih mendalam di luar kelas. ${ }^{57}$

Pesantren Al-Ishlah dan Pesantren Babussalam tidak mengajarkan keragaman mazhab secara komprehensif dalam kurikulum fikih. Hal ini memberikan pengaruh kepada sikap toleransi internal pada para santrinya. Realitas tersebut sejalan dengan apa yang dikemukakan oleh Ibn Taimìah. Menurutnya, jika seseorang dididik dan terbiasa dengan satu mazhab saja hingga ia mempercayai sepenuhnya mazhab tersebut, kemudian ia pun tidak mengetahui dalil hukum dan perbedaan pendapat para ulama, maka ia sesungguhnya adalah muqallid yang hanya menukil pendapat orang lain. Orang tersebut bukan seorang hakim yang dapat memutuskan suatu permasalahan, bahkan ia disebut sebagai pendongeng saja. ${ }^{58}$

Al-Shātibī mengungkapkan hal yang sama dengan Ibn Taimìyah bahwa kebiasaan seseorang dengan mengemukakan dalil dan pendapat fikih dari satu mazhab saja akan membuatnya mengingkari mazhab lain tanpa mengkajinya terlebih dahulu. Di samping itu, sikap tersebut akan merendahkan para mujtahid, yang oleh sebagian lain dikagumi dan dihormati

${ }^{55}$ David Livermore, The Cultural Intelligence Difference: Master the One Skill You Can't Do Without in Today's Global Economy, (New York: American Management Association, 2011), 5http://www.culturalq.com/docs/CQ-Difference-Chapter-1.pdf (diakses 19 Maret 2015).

${ }^{56}$ Danar Widayanato, Miftahuddin, Dinamika Pemikiran Santri: Studi atas Pengaruh Kepemimpinan di Pesantren Wahid Hasyim Sleman (1998-2005), (2007): 6, www.uny.ac.id, (diakses 21 Oktober 2014).

${ }^{57}$ Hasil wawancara penulis dengna ketua Yayasan Babussalam Fadhlullah pada tanggal April 2015.

${ }^{58}$ Taqi al-Dīn Ibn Taimīyah al-Ḥarrāni, Majmū'at al-Fatāwā, vol. 6, (Madinah: Majma‘ al-Malik Fahd, 2004), 202. 
karena kedalaman ilmu mereka tentang agama serta kemampuan mereka mengetahui tujuan-tujuan dari setiap ketentuan hukum. ${ }^{59}$

Tabel 6. Deskripsi Variabel Toleransi Eksternal

\begin{tabular}{|c|c|c|c|c|c|}
\hline & $\mathrm{N}$ & Minimum & Maximum & Mean & Std. Deviation \\
\hline $\begin{array}{c}\text { Fikih_Toleransi } \\
\text { Eksternal }\end{array}$ & 287 & 17 & 35 & 28,48 & 3,543 \\
\hline $\begin{array}{l}\text { Valid N } \\
\text { (listwise) }\end{array}$ & 287 & & & & \\
\hline
\end{tabular}

Dari data tabel di atas dapat disimpulkan bahwa pada toleransi eksternal, nilai rata-rata toleransi adalah 28,48, standar deviasi 3,543, nilai minimum dengan skor 17 dan nilai maksimum dengan skor 35 .

Dari angka mean sebesar 28,48 dengan standar deviasi 3,543 maka skor tinggi, skor sedang, dan skor rendah dapat ditentukan. Adapun hasilnya adalah; skor tinggi sebesar $>32$, skor sedang antara 25-31, dan skor rendah adalah $<24$.

Sementara dari analisis uji beda hubungan antara pesantren dan toleransi eksternal, diperoleh angka signifikansi 0,009, yang lebih kecil dari 0,05 yang berarti hubungan keduanya signifikan. Dengan demikian perbedaan pemahaman dan penanaman toleransi terkait hubungan Muslim dan nonMuslim antara satu pesantren dengan pesantren lainnya masih cukup tinggi. ${ }^{60}$

Tabel 7. Signifikansi Perbedaan Toleransi Eksternal antar Pesantren Toleransi Eksternal

\begin{tabular}{lrrrrr}
\hline & Sum of Squares & Df & Mean Square & F & \multicolumn{1}{c}{ Sig. } \\
\hline Between Groups & 165.991 & 4 & 41.498 & 3.418 & .009 \\
\hline Within Groups & 3423.688 & 282 & 12.141 & & \\
\hline Total & 3589.679 & 286 & & & \\
\hline
\end{tabular}

Adapun tabel berikutnya menunjukkan bahwa pesantren yang memiliki skor mean tertinggi pada fikih toleransi eksternal adalah Pesantren Babussalam dan Pesantren Al-Ishlah dengan masing-masing skor mean

${ }^{59} \mathrm{Abu}$ Isḥāq Ibrāhīm ibn Mūsā ibn Muhammad al-Lakhmī al-Shātibīi, Al-Muwāfaqāt, vol. iv, (al-Mamlakah al-'Arabìyah al-Su'ūđiyah: Dār ibn 'Affān, 1997), 161.

${ }^{60}$ Pesantren pada hakekatnya tetap harus mengikuti ketentuan kurikulum nasional yang sudah ditentukan. Di antara ketentuan tersebut bahwa setiap lembaga pendidikan, termasuk pesantren, harus memperkenalkan agama Islam dan agama-agama lainnya. Ketentuan ini tentu saja menjadi strategis untuk menanamkan toleransi eksternal. Lyn Parker, "Religious Tolerance and Inter-Faith Education in Indonesia", Biennial Conference of the Asian Studies Association, (2010): 4, http://asaa.asn.au/ASAA2010/reviewed_papers/ParkerLynn.pdf., (diakses 20 Oktober, 20, 2015). 
sebesar 29,42. Adapun pesantren dengan tingkat fikih toleransi eksternal terendah adalah pesantren Rafah.

Tabel 8. Level Toleransi Eksternal

Toleransi Eksternal

Tukey $\operatorname{HSD}^{\mathrm{a}, \mathrm{b}}$

\begin{tabular}{llll}
\hline & & \multicolumn{2}{l}{ Subset for alpha $=0.05$} \\
\cline { 3 - 4 } Pesantren & $\mathrm{N}$ & 1 & 2 \\
\hline Pesantren Rafah & 68 & 27.54 & \\
\hline Pesantren Darunnajah & 69 & 28.12 & 28.12 \\
\hline Pesantren Ibnu Abbas & 43 & 28.23 & 28.23 \\
\hline Pesantren Al-Ishlah & 48 & & 29.42 \\
\hline Pesantren Babussalam & 59 & & 29.42 \\
\hline
\end{tabular}

Dari tabel 8 di atas diketahui bahwa Pesantren Babussalam dan AlIshlah memiliki tingkat toleransi eksternal tertinggi dibandingkan dengan pesantren lainnya, sebelumnya kedua pesantren tersebut memiliki tingkat toleransi internal terendah. Sementara 3 pesantren yaitu; Ibnu Abbas, Darunnajah, dan Rafah yang sebelumnya adalah 3 pesantren dengan tingkat toleransi internal tertinggi menunjukkan tingkat toleransi eksternal lebih rendah dari Pesantren Babussalam dan Al-Ishlah.

Dari hasil penelitian kuantitatif terkait toleransi eksternal kemudian ditindaklanjuti dengan penelusuran lebih lanjut secara kualitataif. Pesantren Babussalam sudah terbiasa melakukan kerjasama dengan lembaga pendidikan non-Muslim. Salah satu contoh kegiatan kerjasama tersebut adalah dengan menyelenggarakan kegiatan bersama yang diprakarsai oleh mahasiswa Universitas Kristen Maranata di Bandung. Para mahasiswa tidak sekedar berkunjung akan tetapi juga bercengkerama dengan para santri dalam satu kegiatan yang sama. Bahkan para mahasiswa diberikan kesempatan untuk bermalam di pesantren guna menyaksikan kehidupan keseharian para santri. ${ }^{61}$ Melalui kegiatan tersebut, pesantren berhasil menciptakan lingkungan inklusif dengan membaurkan komunitas Muslim yang diwakili oleh seluruh santrinya, dan komunitas non-Muslim yang diwakili oleh mahasiswa Universitas Maranata. Meskipun interaksi berlangsung dalam waktu yang singkat, akan tetapi pengalaman pembelajaran tersebut sangat efektif dalam memberikan pesan sikap toleransi terhadap perbedaan agama kepada para santri. $^{62}$

\footnotetext{
${ }^{61}$ Hasil wawancara dengan Ketua Yayasan Babussalam Fadlullah pada tanggal 28 April 2015.

${ }^{62}$ Proses pembelajaran melalui praktek atau pengalaman akan jauh lebih melekat pada benak siswa karena melibatkan seluruh potensi indera yang ada. Davaue Meier memiliki 4 konsep pembelajaran yaitu; somatic (bergerak dalam belajar), auditory (berbicara dan
} 
Di Pesantren Al-Ishlah, penghadiran lingkungan inklusif di dalam pesantren dilakukan pada acara-acara seremonial tertentu yang diadakan oleh pesantren. Di antara seremoni yang rutin dilakukan setiap tahun adalah acara Halal Bihalal. Acara tersebut diselenggarakan oleh Pesantren sebagai pembuka proses pembelajaran pasca liburan Ramadhan dan Syawal. Satu hal yang menarik adalah bahwa pesantren mengundang tokoh-tokoh dari agama lain untuk menghadiri acara halal bihalal tersebut. ${ }^{63}$ Tentu saja acara tersebut menjadi sangat strategis dan berpengaruh terhadap para santri, karena ditempatkan di awal rangkaian kegiatan pesantren pasca liburan puasa dan Idul Fitri.

Di samping itu, konsep pendidikan di Pesantren Al-Ishlah memiliki keunikan tersendiri. Jika pesantren pada umumnya menjadi tempat belajar santri siang dan malam, maka santri di Pesantren Al-Ishlah diberikan keleluasaan untuk belajar di lembaga pendidikan lain pada siang harinya. Para santri bebas menentukan sekolah formal yang diinginkan. Konsep ini menurut Gus Qowim agar para santri menerima bekalan yang sempurna baik dari ilmu-ilmu keagamaan ataupun ilmu umum. Di pesantren, santri akan mendapat bekalan untuk mencapaikan kebahagiaan akhirat, sementara di sekolah, mereka akan mendapatkan bekalan demi mencapai kesuksesan di dunia. ${ }^{64}$

Konsekuensi positif dari model pembelajaran di Pesantren Al-Ishlah adalah bahwa santri dapat berinteraksi dengan siswa dari berbagai latar belakang yang berbeda, termasuk perbedaan latar belakang agama. Bahkan salah seorang santri pernah merasakan belajar di satu sekolah yang jumlah siswa Muslimnya lebih sedikit dari non-Muslim. ${ }^{65}$

Berikut penuturan Muhammad Shofi Hidayatullah yang mencerminkan tingginya tingkat toleransi eksternal yang dimiliki;

"Saya sudah terbiasa sekolah bersama teman non-Muslim. Bahkan pada saat belajar di SMP 1 Kediri teman sekelas saya yang nonMuslim lebih banyak daripada yang muslim. Saya dan teman-teman muslim menjaga toleransi terhadap non-Muslim. Ketika ada tugas

mendengar), visual (melihat dan menggambarkan), dan intellectual (pengetahuan dalam proses pembelajaran). Dave Meier, The Accelerated Learning Handbook: A Creative Guide to Designing and Delivering Faster, More Effective Training Programs, (New York: McGraw-Hill, 2000), 90-92.

${ }^{63}$ Hasil wawancara dengan Gus Qowim pada tanggal 7 Mei 2015.

${ }^{64}$ Hasil wawancara dengan Gus Qowim pada tanggal 7 Mei 2015.

${ }^{65}$ Sebagaimana diceritakan salah seorang santri Pesantren Al-Ishlah yang bernama Muhammad Shofi Hidayatullah yang menimba ilmu di Pesantren Al-Ishlah sejak 2010, ketika ia menjadi siswa SMP 1 Kediri. Siswa tersebut saat ini (Mei 2015) melanjutkan studinya di SMA 2 Kediri (sekolah terbaik di kota Kediri), bahkan sekarang ia terpilih menjadi Ketua OSIS di SMA 2 sejak 28 Oktober 2014. Hasil wawancara dengan pada Muhammad Shofi Hidayatullah pada tanggal 8 Mei 2015.

INDO-ISLAMIKA, Volume 5 No. 2 Juli - Desember 2015/1438 | 233 
kelompok, kemudian ada kewajiban shalat, maka saya minta izin untuk melaksanakannya sebagai kewajiban agama. Ketika ada kegiatan di hari Minggu, teman-teman non-Muslim saya persilahkan untuk pergi ke Gereja terlebih dahulu baru kemudian kegiatan dilanjutkan setelah itu. Saat ini saya menjadi ketua OSIS di SMA, saya berusaha memberikan dukungan juga pada kegiatan agama lain seperti; agama Kristen Protestan, dan Katolik. Saya memotivasi mereka untuk membuat kegiatan mingguan, bulanan seperti yang ada dalam kegiatan Islam. Saya tidak membedakan antara agama satu dan yang lain. Dalam menyambut Ramadhan, mereka juga saya minta untuk mengadakan kegiatan sesuai agama mereka. Jika saya diundang dalam kegiatan agama mereka, maka saya membuat sambutan tertulis untuk disampaikan pada acara tersebut. Proses saya terpilih menjadi ketua OSIS juga tidak mudah. Saat pemilihan saya menyampaikan bahwa perbedaan agama tidak menjadi masalah. Kita bersaudara karena belajar di sekolah yang sama dan ingin memajukan sekolah ini." 66

Dua fenomena di atas baik di Pesantren Babussalam dan al-Ishlah adalah salah satu bentuk penanaman toleransi eksternal, di mana hal-hal yang sebelumnya tidak mungkin dilakukan kemudian dapat dilakukan. Kerjasama antara pesantren dengan universitas Maranata untuk mengadakan kegiatan bersama sehingga terjadi pembauran yang alami antara Muslim dan nonMuslim pada awalnya tidak mungkin, akan tetapi argumentasi yang logis dan rasional menjadikan kegiatan tersebut dapat dilaksanakan. ${ }^{67}$

Realitas yang ada di Pesantren Babussalam dan Al-Ishlah pada awalnya sesuatu yang ganjil dan asing, ketika pesantren yang kuat dengan identitas keislamannya membangun interaksi secara intensif dengan komunitas non-Muslim. Namun secara bertahap hal itu sudah menjadi kebiasaan di kedua pesantren tersebut. Hal inilah yang oleh Russel Powell dan Steve Clarke disebut sebagai sebuah toleransi. Menurut keduanya, toleransi adalah tindakan melakukan sesuatu yang sebelumnya terasa berat, tetapi kemudian dengan upaya rasionalisasi, tindakan tersebut menjadi dapat diterima tanpa keberatan. ${ }^{6}$

Sementara di Pesantren Ibnu Abbas, Darunnajah dan Rafah tidak memiliki kegiatan berskala besar yang melibatkan seluruh santri dan komunitas non-Muslim. Hanya di Pesantren Darunnajah yang kadangkala

\footnotetext{
${ }^{66}$ Hasil wawancara dengan pada M. Shofi Hidayatullah pada tanggal 8 Mei 2015

${ }^{67}$ Wawancara dengan Ketua Yayasan Babussalam, Fadulullah, tanggal 28 April 2015

${ }^{68}$ Russell Powell, Steve Clarke, Religion, Tolerance, and Intolerance: Views from Across the Disciplines, University of Oxford, http://www.philosophy.ox.ac.uk/_data/assets/pdf_file/0013/13504/Tolerance5_background_ reading.pdf, (diakses tanggal $27 \overline{\mathrm{Me}} \mathrm{2015}$ ).
} 
menerima kunjungan formal dari tamu-tamu non-Muslim. Hal ini menunjukkan adanya interaksi dengan non-Muslim akan tetapi tidak melibatkan seluruh santri dan kegiatan tersebut bersifat formal.

Fenomena di atas dapat dilihat dari perspekif tiga model bagaimana lembaga pendidikan agama mengajarkan materi pembelajaran keagamaan yang dikemukakan Agus Nuryatno. Ketiga model tersebut adalah: Pertama, pendidikan agama in the wall, yaitu model pendidikan agama yang hanya mengkaji dan memahami agamanya sendiri dan meninggalkan agama-agama yang lainnya. Kedua, pendidikan agama at the wall yaitu pendidikan agama yang tidak hanya mengkaji dan memahami agamanya sendiri akan tetapi juga memahami agama yang lainnya. Ketiga, pendidikan agama beyond the wall, pendidikan agama yang membantu siswanya untuk dapat bekerjasama dengan siswa yang berlainan agama demi lahirnya kehidupan yang damai dan harmoni. ${ }^{69}$

Jika dilihat dari teori model pendidikan Islam, maka jelas sekali bahwa Pesantren Babussalam dan Pesantren Al-Ishlah memiliki konsep lebih maju dengan melakukan penanaman agama beyond the wall. $^{70}$ Model ini ditunjukkan dengan pengalaman pembelajaran para santri di kedua pesantren tersebut. Di Pesantren Babussalam pembelajaran agama dilakukan dengan memfasilitasi santri untuk dapat bekerjasama dengan komunitas nonMuslim, dengan demikian toleransi terhadap Non-Muslim tidak hanya secara teoritis disampaikan akan tetapi hingga pada praktek dan perilaku. ${ }^{71}$ Begitu pula di Pesantren Al-Ishlah, interaksi dan kerjasama dilakukan dengan menghadirkan tokoh-tokoh Non-Muslim pada acara internal pesantren seperti kegiatan Halal Bihalal. Di samping itu, pada tingkat pimpinan, pihak pesantren dan pihak Non-Muslim menjalin kerjasasama dalam wadah organisasi FKUB. ${ }^{72}$ Dengan wadah tersebut, secara berkala para tokoh agama

\footnotetext{
${ }^{69}$ Teori yang dikemukakan oleh M. Agus Nuryatno merupakan pengembangan dari teori yang dikemukakan oleh Jack Seymour dan Tabitha Kartika Christiani. M. Agus Nuryatno, "Islamic Education in a Pluralistic Society", Al-Jāmi 'ah, vol. 49, no. 2, (2011): 421, lihat juga Tabita Kartika Christiani, "Christian Education for Peacebuilding in the Pluralistic Indonesian Context", Religion, Civil Society, and Conflict in Indonesia, Zurich: t.p., 2009, 173-175.

${ }^{70}$ M. Agus Nuryatno, "Islamic Education in a Pluralistic Society", Al-Jāmi ‘ah, vol. 49, no. 2, (2011), 411-412.

${ }^{71}$ Contoh kerjasama seperti diuraikan sebelumnya, bahwa Pesantren Babussalam menjalin kerjasama dengan Universitas Maranata dalam bentuk pengadaan kegiatan bersama di lingkungan pesantren. Mahasiswa Universitas tersebut diperkenankan bermalam di pesantren saat pelaksanaan kegiatan. Hasil wawancara dengan Ketua Yayasan Babussalam, Fadlullah, pada tanggal 28 April 2015.

${ }^{72}$ FKUB kepanjangan dari Forum Kerukunan Umat Beragama adalah forum yang dibentuk oleh masyarakat dan difasilitasi oleh Pemerintah dalam rangka membangun, memelihara, dan memberdayakan umat beragama untuk kerukunan dan kesejahteraan.
}

INDO-ISLAMIKA, Volume 5 No. 2 Juli - Desember 2015/1438 | 235 
dapat bertemu dalam rangka berbagi informasi agar dapat menguatkan kebersamaan meskipun dengan latar belakang agama yang berbeda di kota Kediri. $^{73}$

Sementara Pesantren Ibnu Abbas, Darunnajah, dan Rafah melakukan penanaman agama pada model "at the wall' yakni pembelajaran agama dan agama lainya dengan pendekatan teoritis saja tanpa ada upaya membangun interaksi dengan pemeluk agama yang berbeda.

\section{KESIMPULAN}

Berdasarkan hasil pembahasan di atas dapat disimpulkan bahwa pengenalan keragaman, baik keragaman mazhab dalam Islam dan keragaman agama di tengah masyarakat, dapat melahirkan sikap toleransi. Pesantren modern memiliki program pengenalan keragaman mazhab, yang dengan pengenalan tersebut mampu membentuk perilaku santri yang toleran dengan perbedaan sesama Muslim yang dalam hal ini disebut dengan toleransi internal. Model toleransi ini akan mengikis berbagai bentuk perselisihan dan perpecahan yang dilatarbelakangi oleh perbedaan di dalam Islam itu sendiri. Begitu pula dengan pesantren tradisional, dengan berbagai pola penenaman toelransi eksternal melalui interaksi dan kerjasama dengan non-Muslim, secara efektif memberikan pengaruh positif pada penanaman toleransi terhadap non-Muslim.

Dengan demikian masing-masing model pesantren, baik pesantren modern ataupun tradisional, memiliki kelebihan dan keunggulan yang pada akhirnya dapat menjadi media penyempurna positif di antara keduanya. Pesantren modern dapat menyempurnakan proses penanaman toleransi eksternal dengan mengadopsi proses yang dijalankan oleh pesantren tradisonal, begitu pula pesantren tradisonal dapat memperbaharui proses penanaman toleransi internalnya dengan mengadopsi bagaimana pesantren modern menanamkan nilai tersebut kepada para santrinya.

Pemerintah dalam hal ini sebagai pemangku kebijakan dapat mengambil unsur-unsur positif dari pesantren modern dan pesantren tradisional yang dapat dijadikan sebagai standar model pesantren secara umum di Indonesia. Dengan upaya ini, secara bertahap stigma negatif pesantren sebagai tempat penanaman nilai-nilai radikalisme dapat dihilangkan. Pesantren memiliki peran yang sangat strategis sebagai wadah penanaman nilai-nilai yang efektif, maka sudah seharusnya nilai-nilai yang ditanamkan di dalamnya adalah nilai-nilai positif termasuk nilai toleransi internal dan eksternal. Pemerintah harus dapat mengambil peran penjamin bahwa hanya nilai-nilai positif tersebut yang akan ditanamkan dan

Menteri Agama, Menteri Dalam Negeri, Peraturan Bersama, No. 8 dan 9, (2006): 4, http://kemenag.go.id/file/dokumen/PERMEN906.pdf, diakses 25 Juni 2015.

${ }^{73}$ Hasil wawancara dengan Pendeta Lumbana pada tanggal 8 Mei 2015. 
dikembangkan di pesantren. Jika peran ini dapat dilakukan sehingga melahirkan sinergi positif antara pesantren dan pemerintah, maka secara bertahap nilai-nilai keislaman yang berkembang di masyarakat adalah nilainilai Islam yang mencerminkan toleransi baik sesama Muslim ataupun terhadap non-Muslim yang sudah dicontohkan dalam sejarah perjalanan Rasululullah SAW.

\section{DAFTAR PUSTAKA}

\section{BUKU}

Abdillah, Masykuri, Islam dan Demokrasi: Respons Intelektual Muslim Indonesia terhadap Konsep Demokrasi 1966-1993, Jakarta: Prenadamedia Group, 2015

Azra, Azyumardi, Jejak-jejak Jaringan Kaum Muslim; Dari Australia hingga Timur Tengah, Jakarta: Hikmah, 2007.

Bagir, Zainal Abidin, dkk., Laporan Tahunan Kehidupan Beragama di Indonesia 2012, Yogyakarta: CRCS-UGM, 2012.

Dhofier, Zamakhsyari, Tradisi Pesantren: Studi Pandangan Hidup Kyai dan Visinya Mengenai Masa Depan Indonesia, Jakarta: LP3ES, 2011.

Fradkin, Hillel, Husain Haqqani, and Eric Brown (eds.), Current Trends in Islamic Ideology, vol. 2, Washington: Hudson Institute, 2005.

Hardijanto, Soegeng, (et. al.), Agama dalam Dialog: Pencerahan, Pendamaian dan Masa Depan, Jakarta: BPK Gunung Mulia, 2003.

Harrāni, Taqi al-Dīn Ibn Taimìyah,Majmū ‘ Fatāwā, vol. 6, Madinah: Majma“ al-Malik Fahd, 2004.

Hidayat, Surahman, Islam Pluralisme dan Perdamaian, Jakarta: Fikr, 2008.

Ji, Hamid Muhammad Rawas, Qal'ah Șadūq Qanaibī, Mu'jam Lughah alFuqaha', Bairūt: Dār al-Nafa' is, 1988.

Livermore, David, The Cultural Intelligence Difference: Master the One Skill You Can't Do Without in Today's Global Economy, New York: American Management Association, 2011.

Ma'luf, Louis, al-Munjid fi al-Lughah, Bairut: Dar al-Mashriq, 1997.

Madjid, Nurcholish, Islam Doktrin dan Peradaban, Jakarta: Paramadina, 1999

Manzūur, Muhammad ibn Mukrim ibn, Lisān al-'Arab, vol. xiii, Bairūt: Dār Sāadir, 1994.

Meier, Dave, The Accelerated Learning Handbook: A Creative Guide to Designing and Delivering Faster, More Effective Training Programs, New York: McGraw-Hill, 2000.

Qomar, Mujamil, Pesantren; dari Transformasi Metodologi Menuju Demokratisasi Institusi, Jakarta: Erlangga, 2007.

INDO-ISLAMIKA, Volume 5 No. 2 Juli - Desember 2015/1438 | 237 
Abdul Ghoni

Risakotta, Bernard Adeney, ed., Dealing with Diversity; Religion, Globalization, Violence, Gender, and Disaster in Indonesia, Geneva: Globethics.net International Secretariat, 2014.

Rodger, Alex R., Educational and Faith in Open Society, Britain: The Handel, 1982.

Sābiq, Al-Sayyid, Fiqh al-Sunnah, vol. 1, Lubnān: Dār al-Fikr, 1983.

Sairin, Weinata, Kerukunan Umat Beragama: Pilar Utama Kerukunan Berbangsa, Jakarta: BPK Gunung Mulia, 2006.

Sha'bān, Abd al-Ḥusaīn,Fiqh al-Tasāmuḥ fî al-Fikr al-'Arabī al-Islāmī, Arbìl: Dār 'Aras, 1998.

Shạtibì, Abū Ishạa Ibrāhīm ibn Mūsā ibn Muhammad al-Lakhmī, AlMuwāfaqāt, vol. iv, al-Mamlakah al-'Arabīyah as-Su'ūdiyah: Dār ibn 'Affān, 1997.

Singh, Anita Inder, Democracy, Ethnic Diversity, and Security in Postcommunist Europe, London: Praeger, 2001.

Subki, 'Ali 'Abd al-Kafi, al-Ibhaj, vol. 1, Bairut: Dar al-Kutub al-'Ilmiyah, t.t.

Suparta, Mundzier, Perubahan Orientasi Pondok Pesantren Salafiyah terhadap Perilaku Keagamaan Masyarakat, Jakarta: Asta Buana Sejahtera, 2009.

'Ukāshah, Mạ̣mūd, Huqūq al-Zaujah fī al-Islām, Qāhirah: al-Akadimīyah al-Hadithah li al-Kitāb al-Jāmi ‘َi, 2006.

Wagiman, Suprayetno, The Modernization of the Pesantren's Educational System to Meet the Needs of Indonesia Communities, Montreal: McGill University, 1997.

Webster, Merriam, The Merriam Webster Dictionary, New York: Merriam Co., 1976

\section{JURNAL}

Andari, Ken, dkk., "Konstruksi Majalah Gatra tentang Radikalisme di Pesantren," Students e-journals, (2012): http://jurnal.unpad.ac.id/ejournal, (diakses 3 Februari 2015).

Finkel, Steven E. and Amy Erica Smith, Civic Education, Political Discussion, and the Social Transmission of Democratic Knowledge and Values in a New Democracy: Kenya 2000, American Journal of Political Science, vol. 55, no. 2 (April 2011): 417-435, www.jstor.org/stable/23025060 (diakses 19 Desember 2014).

Furkhan, Nuril, "The Implementation of Character Education through the School Culture in SMA Negeri 1 Dompu and SMA Negeri Kilo 
Dompu Regency," An Open Access International Journal, vol. 3, (2014): 14-44.

Hoskins, Bryony Louise, and others, "Comparing Civic Competence among European Youth", Chicago Journals, (2011): 82-110, http://www.jstor.org /stable/10.1086/656620, (diakses 19 Desember 2014).

Nuryatno, M. Agus, "Islamic Education in a Pluralistic Society", Al-Jāmi 'ah, vol. 49, no. 2, (2011).

Pohl, Florian, "Islamic Education and Civil Society; Reflections on the Pesantren Tradition in Contemporary Indonesia", Chicago Journals, vol. 50, no. 3, (2006): 389-409, www.jstor.org/stable/10.1086/503882 (diakses 27 Maret 2014).

Purta, Judith Torney, "Patterns in the Civic Knowledge, Engagement, and Attitudes of European Adolescents: The IEA Civic Education Study", European Journal of Education, vol. 37, no. 2, (2002).

Romadlan, Said, Rekayasa Sosial Adopsi Teknologi Komunikasi di Kalangan Pondok Pesantren Muhammadiyah, Jurnal Lemlit Uhamka, (2013): 83-91, http://www.seminar-uhamka.net/uploads/3/2/8/0/3280177/ maqrav2n2 2013 _11_said-hal.pdf, (diakses 30 Januari 2015).

\section{WEBSITE}

Ashrāf, Abū,al-Ikhtilāfāt al-Fiqhīyah wa Atharuhā fì Takwīn al-Malakah wa Tanmiyyatuhā, (2012), http://www.hadaik.com/vb/showthread.php?t=7390 (diakses 25 Februari 2015).

Hoodbhoy, Pervez, "Islam and Pluralism in the Modern Muslim State", Islam and Pluralism, (April 2011): 1-8, http://eacpe.org/content/uploads/2014/ 02/Islam-and-pluralism-inthe-modern-Muslim-state.pdf. (diakses 25 Oktober 2015).

'Ijlān, Fahd Salāh, Al-Tasāmuḥ al-Fiqhī, http://uqu.edu.sa /page/ar/185865 (diakses 5 April 2014).

Islamic Conference of Culture Ministers, Islamic Declaration on Cultural Diversity, (2004): http://www.usc.edu/schools/college/crcc/private/cmje/heritage/Isla mic Cultural Diversity.pdf., (diakses 21 Oktober 2015).

Maksum, Ali, Model Pendidikan Toleransi di Pesantren Modern dan Salaf, (2013): 1-20, http://eprints.uinsby.ac.id/121/1 (diakses 19 Desember 2014). 
Abdul Ghoni

Menteri Agama, Menteri Dalam Negeri, Peraturan Bersama, No. 8 dan 9, (2006): 4, http://kemenag.go.id/file/dokumen/PERMEN906.pdf, diakses 25 Juni 2015.

Parker, Lyn, "Religious Tolerance and Inter-Faith Education in Indonesia", Biennial Conference of the Asian Studies Association, (2010): 114, http://asaa.asn.au/ASAA2010/reviewed_papers/ParkerLynn.pdf., (diakses 20 Oktober 2015).

Powell, Russell and Steve Clarke, Religion, Tolerance and Intolerance: Views from Across the Disciplines, Oxford: University of Oxford, t.t., http://www.philosophy.ox.ac.uk/data/assets/pdf file/0013/13504/T olerance5backgroundreading.pdf (diakses 27 Mei 2015).

Ritchey, Jeffrey A., and Nurhaya Muchtar, Indonesian Pesantrenand Community Social Change: Moderate Islam's Use of Media and Technology for Nonformal, Community, (2014): 420-425, http://www.adulterc.org (diakses 30 Januari 2015).

United States Institute for Peace (USIP), "Ijtihad: Reinterpreting Islamic Principles for the Twenty-First Century", Special Report, Wahington, (August, 2004): 1-2, http://www.usip.org/sites/default /files/sr125.pdf (diakses 21 Oktober 21,2015).

Widiyanta, Danar, Miftahuddin, Dinamika Pemikiran Santri: Studi atas Pengaruh Kepemimpinan di pondok Pesantren Wahid Hasyim Condongcatur Depok Sleman (1998-2005), (2007): 1-20, www.uny.ac.id (diakses 21 Oktober 2014).

http://www.bbc.co.uk/indonesia/laporan_khusus/2011/10/111011_pesantrend anradikalisme.shtml, (diakses tanggal 3 Februari 2015).

http:/www.bbc.com/indonesia/laporan khusus/2012/10/121012 insidengruki school.shtml (diakses 19 Januari 2016).

http:/nasional.tempo.co/read/news/2006/02/05/05573468/alumni-ngrukihernianto-seorang-mujahid (diakses 19 Januari 2016).

http://www.gatra.com/hukum-1/781-polisi-cari-pimpinan-ponpes-umar.html. (diakses 21 Januari 2016).

http://www.gatra.com/hukum-1/890-polisi-temukan-bom-aktif-di-bima.html. (diakses 21 Januari 2016 